\title{
PENCALONAN KEPALA DAERAH PADA PEMILIHAN SERENTAK 2020 DI SULAWESI SELATAN
}

\author{
Syarifuddin Jurdi \\ UIN Alauddin Makassar dan KPU Sulawesi Selatan \\ Email: sjurdi06@gmail.com
}

\begin{abstract}
Abstrak
Pencalonan kepala daerah pada pemilihan serentak tahun 2020 di Sulawesi Selatan menghadapi dinamika yang tidak sama, pasangan calon harus memenuhi persyaratan pencalonan dan syarat calon yang disertakan ketika mendaftar. Untuk memenuhi persyaratan pencalonan, pasangan calon memerlukan dukungan partai politik atau gabungan partai politik, perebutan rekomendasi partai politik pada beberapa kabupaten/kota sangat dinamis, terdapat pasangan calon yang kehilangan partai politiknya menjelang pendaftar, pada kabupaten lain terjadi lobi politik untuk merebut rekomendasi partai yang sudah diberikan kepada pasangan lain. Sementara pada dua kabupaten (Gowa dan Soppeng), perebutan rekomendasi partai politik tidak terjadi, karena pasangan calon tunggal. Sementara calon perseorangan pada Kabupaten Kepulauan Selayar yang memenuhi syarat minimal dukungan justru mendaftar dengan menggunakan jalur partai politik. Semua pasangan yang gonjang ganjing dukungan politiknya segera mendaftar pada hari pertama pembukaan pendaftaran. Satu kasus lagi, terdapat pasangan calon yang gagal ditetapkan sebagai pasangan karena dinyatakan positif penyalahgunaan narkotika, sedangkan dua pasangan calon mengalami penundaan penetapan sebagai pasangan, karena positif Covid-19 dan menunggu sampai dinyatakan negatif Covid-19 baru diteruskan pemeriksaan kesehatannya.
\end{abstract}

\section{Kata Kunci:}

Pilkada, Rekrutmen, Pasangan Calon, Kepala Daerah

\begin{abstract}
The concurrent election 2020 in South Sulawesi faced dynamic circumstances as the pairs of candidates must fill the requirements when registering themselves. During the process of regional election, some cases happened in some regions in South Sulawesi. As an example, some candidates in some regions might lose support from the political parties in the middle of the election process as the support from the political party is unstable. On the other hand, special cases happened in two districts (Gowa and Soppeng), where there was only one single candidate for each region. Hence the struggle to get the support of a political party did not occur in both areas. In another region, Selayar, the individual candidate who has already fulfilled the minimum requirement still seeks support from political parties. All candidates tend to register themselves as fast as possible to prevent the failure in registration stage. Another case shows that there was a pair of candidates who failed to be a partner because they were tested positive for narcotics use, while two candidate pairs experienced a delay in
\end{abstract}


registration because they were positive for Covid-19 and the had to wait until they were tested negative for Covid-19 before continuing to the medical check-up stage.

\section{Keywords:}

Regional Election, Recruitment, Regional Leaders

\section{Pendahuluan}

Pemilihan Umum (Pemilu) merupakan rangkaian proses seleksi dan rekrutmen kepemimpinan politik atau pejabat eksekutif dan pejabat legislatif. Pemilu menjadi sarana bagi para politisi untuk memperebutkan jabatan politik dan pemilihan sebagai arena perebutan posisi elite pemerintahan di daerah. Melalui pemilihan, elite politik yang bersaing untuk memperoleh dukungan rakyat dengan cara menyampaikan gagasan dan programnya untuk memecahkan masalah-masalah aktual yang dihadapi masyarakatnya, melalui penyampaian gagasan dan program tersebut rakyat akan menilai dan mengevaluasi setiap kandidat, agar dapat memperoleh dukungan rakyat, elite hanya mengampanyekan ide tentang perubahan, perbaikan dan transformasi sosial masyarakat menjadi lebih bermartabat dan sejahtera.

Pemilihan Kepala Daerah (Pilkada) serentak 2020, elite politik mensosialisasikan program yang akan dilakukan apabila terpilih sebagai kepala daerah. Visi, misi dan program kandidat kepala daerah berangkat dari dua kecenderungan utama, yakni fenomena sosial masyarakat yang sedang terjadi dan imajinasi elite mengenai transformasi masa depan daerah. Visi ideal mengenai masyarakat serta realitas politik yang dihadapi merupakan titik temu antara yang idealitas dengan yang praktis.

Pilkada secara langsung yang telah diselenggarakan sejak tahun 2005 dan pemilihan serentak yang dilakukan pertama kali pada tahun 2015 merupakan upaya untuk menghasilkan kepemimpinan daerah dan memupuk demokrasi. Kualitas demokrasi akan ditentukan oleh proses pemilihan kepemimpinan nasional dan kepemimpinan daerah yang dilakukan secara langsung oleh rakyat. Pilkada secara langsung sebagai suatu mekanisme untuk mewujudkan kedaulatan rakyat sebagaimana amanat konstitusi, hak rakyat dalam menentukan kepemimpinan, rakyat pula yang dapat melakukan seleksi terhadap kandidat, bahkan rakyat dapat memilih pemimpin alternatif dari calon yang tidak diusulkan oleh partai politik pemenang Pemilu, yakni kandidat yang muncul melalui calon perseorangan. 
Pilkada secara langsung merupakan sarana untuk menciptakan demokrasi dengan memaksimalkan partisipasi masyarakat pemilih dalam menentukan pemimpinnya. Dalam sistem demokratis, preferensi warga secara adil diperhitungkan dalam proses pengambilan keputusan dan terefleksi dalam hukum dan kebijakankebijakan pemerintah. ${ }^{1}$ Sistem pemerintahan disebut demokratis tidak hanya dilihat dari kemampuan elite untuk merespon aspirasi warganya, tetapi kepemimpinan tersebut harus dihasilkan dari satu proses Pemilu yang dilakukan secara periodik, langsung, umum, bebas, rahasia, jujur dan adil. Pemilu merupakan sarana untuk memobilisasi dan menggerakkan dukungan rakyat terhadap pemerintah dengan jalan ikut serta dalam proses politik.

Pencalonan merupakan bagian tak terpisahkan dari sistem Pemilu, mekanisme pencalonan dilakukan oleh pengurus partai politik di tingkat daerah, dan negara yang menganut sistem proporsional, mekanisme pencalonan cenderung dilakukan tersentralisasi, namun dalam pencalonan kepala daerah di Indonesia dengan sistem Pilkada terjadi formula perolehan suara terbanyak dalam Pilkada, ternyata tidak menjadikan mekanisme pencalonan terdesentralisasi, malahan cenderung semakin tersentralisasi. ${ }^{2}$ Dalam ketentuan perundang-undangan bahwa penentuan calon kepala daerah dan wakil kepala daerah dilakukan oleh setiap partai politik secara demokratis dan terbuka. ${ }^{3}$

Pencalonan yang disebut demokratis apabila setiap individu atau kandidat bersaing secara terbuka dan bebas untuk memperoleh dukungan politik, partai politik dengan legitimasi dari anggotanya akan mendukung kandidat yang memiliki keunggulan untuk diusulkan sebagai calon kepala daerah. Mekanisme yang dapat dilakukan oleh partai politik untuk menentukan pasangan calon bisa melalui konvensi, polling, survei dan atau rapat umum yang melibatkan anggota partai politik. ${ }^{4}$ Penentuan pasangan calon kepala daerah didahului oleh survei politik melalui lembaga survei, baik (2012).

${ }^{1}$ Rahmatunnisa Mudiyati, "Desentralisasi dan Demokrasi” dalam Jurnal Governance, Vol 1, No 2

${ }^{2}$ Hasyim Asy'ari, Konsolidasi Demokerasi: Pergulatan Politik Pemilu di Indonesia (Yogyakarta: Thafa Media, 2019), h. 229-234.

${ }^{3}$ Ramlan Surbakti, dkk., Naskah Akademik dan Draft RUU Kitab Hukum Pemilu: Usulan Masyarakat Sipil (Jakarta: Kemitraan bagi Pembaruan Tata Pemerintahan di Indonesia, 2015), h. 179.

${ }^{4}$ Lihat misalnya Syarifuddin Jurdi, Pemilihan Umum di Indonesia: Tata Kelola Pemilu, Kedaulatan Rakyat dan Demokratisasi (Jakarta: Kencana Prenada Media Gorup, 2020), khususnya bab 6 pencalonan legislatif dan eksekuti. 
internal partai politik maupun dilakukan oleh kandidat untuk mengukur tingkat elektabilitas calon. Metode yang paling lazim digunakan adalah survei, sementara metode konvensi seperti dalam penentuan calon presiden oleh Partai Golkar tahun 2004 belum digunakan dalam penentuan calon kepala daerah.

Pilkada secara langsung merupakan arena kompetisi dan kontestasi antar elite politik. Pilkada mempertimbangkan $;^{5}$ pertama, pemilihan harus dilaksanakan secara demokratik yang memberi peluang bagi calon kepala daerah untuk berkompetisi secara fair dan jujur. Kedua, Pilkada secara langsung harus diarahkan pada terpilihnya kepala daerah yang lebih baik, lebih berkualitas, dan memiliki akuntabilitas politik yang tinggi dan derajat legitimasi yang lebih kuat karena kepala daerah yang terpilih mendapat mandat langsung dari rakyat. Ketiga, pelaksanaan pemilihan bersifat praktis, dalam arti proses dan tahapan pemilihan tidak rumit dan mudah dimengerti oleh masyarakat. Praktik proses pemilihan harus dilangsungkan dengan lebih sederhana dan penetapan hasil pemilihan dilakukan secara terbuka dan transparan.

Pencalonan merupakan bagian dari rekrutmen politik untuk memilih pejabat politik melalui suatu pemilihan yang demokratis. Rekrutmen politik menurut Ramlan Surbakti ${ }^{6}$ merupakan proses politik sebagai seleksi dan pemilihan atau pengangkatan seseorang atau sekelompok orang untuk melaksanakan sejumlah peranan dalam sistemsistem politik pada umumnya dan pemerintahan pada khususnya. Fungsi rekrutmen merupakan fungsi dari mencari dan mempertahankan dan melaksanakan tugas-tugas negara. Fungsi rekrutmen bagi KPU sangat menentukan bekerjanya instrumen penyelenggaraan Pemilu. Rekrutmen dapat diartikan sebagai penyeleksian terhadap individu ataupun sekelompok orang dalam penempatan sebagai penyelenggara Pemilu.

Rekrutmen menurut Afan Gaffar $^{7}$ merupakan proses pengisian jabatan politik dalam sebuah negara, agar sistem politik dapat memfungsikan dirinya dengan sebaikbaiknya, guna memberikan pelayanan dan perlindungan masyarakat. Poin penting adalah fungsi pelayanan dan perlindungan terhadap masyarakat. Dalam definisi yang lain, rekrutmen politik sebagai suatu proses dimana idividu dilibatkan dalam peran-

\footnotetext{
5Joko J. Prihatmoko, Mendemokrasikan Pemilu: Dari Sistem Sampai Elemen Teknis (Yogyakarta: Pustaka Pelajar, 2008), h. 148.

${ }^{6}$ Ramlan Surbakti, Memahami Ilmu Politik. (Jakarta: Erlangga, 1992), h. 118; Syarifuddin Jurdi, Pemilihan Umum di Indonesia: Tata Kelola Pemilu, Kedaulatan Rakyat dan Demokratisasi (Jakarta: Kencana Prenada Media, 2020).

${ }^{7}$ Afan Gaffar, Politik Indonesia; Transisi Menuju Demokrasi (Yogyakarta: Pustaka Pelajar, 1999), h. 155.
} 
peran politik aktif. Rekrutmen penyelenggara ad hoc pada KPU merupakan proses pengisian jabatan dengan melibatkan partisipasi aktif masyarakat untuk ikut terlibat dalam proses penyelenggaraan Pemilu. Mereka yang terseleksi dan terpilih pada posisi sebagai penyelenggara ad hoc Pemilu dapat berperan memberikan pelayanan kepada masyarakat secara efektif dan cepat demi terselenggaranya Pemilu yang langsung, umum, bebas, rahasia, jujur dan adil (luber-jurdil).

\section{Metode Penelitian}

Pencalonan merupakan tahapan penting dalam Pilkada, melalui pencalonan akan ditetapkan pasangan calon yang memenuhi syarat sebagai pasangan calon yang akan mengikuti pemilihan. Setiap tahapan dalam pemilihan memegang posisi dan peran strategis. Oleh sebab itu, tahapan pencalonan menjadi pintu bagi penyelenggara Pemilu untuk menentukan proses tahapan selanjutnya seperti kampanye, pengadaan logistik dan lain sebagainya. Melalui tulisan ini akan menjawab pertanyaan atau masalah pokok yakni; pertama, bagaimana proses pencalonan kepala daerah pada Pilkada serentak tahun 2020?. Kedua, bagaimana pencalonan kepala daerah pada Pilkada serentak 2020 dalam kondisi pandemi Covid-19?. Ketiga, apakah semua pasangan calon memenuhi protokol kesehatan dalam pendaftaran pencalonannya?.

Untuk menjawab pertanyaan tersebut, tulisan ini akan dimulai dengan melakukan pemetaan terhadap data berdasarkan fenomena sehingga mempermudah untuk membangun narasi atau argumentasi. Pendekatan atau metode yang digunakan dalam tulisan ini adalah verstehen atau pemahaman dan interpretasi terhadap suatu objek yang mempunyai makna (meaning-full forms) dengan tujuan untuk menghasilkan kemungkinan pemahaman yang objektif. ${ }^{8}$ Oleh sebab itu, tulisan ini akan melakukan proses analisis yang objektif dan berkualitas dengan mendasarkan pada peristiwa dan keadaan yang sungguh-sungguh ada.

\section{Pencalonan Kepala Daerah pada Pilkada Serentak 2020}

Pemilihan merupakan arena para kandidat untuk memperoleh dukungan politik dan kesempatan memperebutkan suara pemilih. Kandidat kepala daerah memiliki

${ }^{8}$ Josef Bleicher, Contemporary Hermeneutics: Hermeneutics as Method, Philosophy and Critique (London: Routledge, 1980), h. 28. 
kesempatan untuk berkompetisi dalam memperebutkan dukungan rakyat, melalui suatu pemilihan yang demokratis dan transparan. Calon kepala daerah dapat menempuh dua pintu agar dapat mendaftarkan diri sebagai pasangan, yakni melalui pintu partai politik dan calon individual atau perseorangan. Pencalonan yang dilakukan melalui partai politik ditentukan berdasarkan kriteria dan mekanisme internal partai politik, misalnya menggunakan survei elektabilitas calon atau menggunakan mekanisme penjaringan mulai struktur partai terbawah hingga pada tingkat kabupaten/kota. Sementara pasangan calon perseorangan ditentukan melalui mekanisme dukungan politik yang diberikan oleh warga dan dukungan tersebut benar adanya setelah penyelenggara Pemilu melakukan verifikasi faktual.

Pencalonan merupakan proses yang dinamis, kandidat yang memiliki tingkat elektabilitas tinggi, dukungan publik kuat, basis massa jelas dan kekuatan finansial memadai, pasangan dengan keunggulan seperti ini akan lebih mudah memperoleh dukungan partai politik. Proses pencalonan juga diwarnai dengan isu politik uang, mahar politik atau upaya lain yang membuat partai politik memutuskan untuk mendukung pasangan calon tertentu. Dukungan partai terhadap pasangan calon tidak hanya diperoleh dari pimpinan partai pada tingkat kabupaten/kota, melainkan dukungan dari pimpinan tingkat provinsi, dan terutama pimpinan partai tingkat pusat yang mengeluarkan rekomendasi terhadap pasangan calon. Dalam pendaftaran pasangan calon, rekomendasi atau persetujuan partai politik atau gabungan partai politik tingkat pusat menjadi persyaratan utama. ${ }^{9}$

Pasangan calon yang telah memperoleh rekomendasi atau persetujuan dari pimpinan partai politik tingkat pusat yang akan mendaftar sebagai pasangan dan didampingi oleh Ketua dan Sekretaris Partai Politik kabupaten/kota. Dokumen pencalonan dan syarat calon merupakan dokumen yang harus disediakan oleh pasangan calon sebelum mendaftar ke KPU kabupaten/kota. Pencalonan kepala daerah serentak 2020 pada beberapa daerah yang menyelenggarakan Pilkada serentak di Provinsi Sulawesi Selatan mengalami dinamika yang tidak sama, terdapat daerah yang memiliki intensitas dan persaingan politik tinggi, namun adapula daerah yang memunculkan calon tunggal. Proses pencalonan kepala daerah di Sulawesi Selatan dapat dijelaskan

${ }^{9}$ Peraturan KPU No. 1 Tahun 2020, Pasal 39 ayat 1 dan 2. 
dengan mengacu pada dinamika politik yang dihadapi oleh masing-masing daerah, setidaknya terdapat empat varian proses pencalonan kepala daerah di Sulawesi Selatan pada Pilkada serentak 2020.

Pertama, munculnya calon perseorangan yang sudah melakukan pendaftaran pada KPU daerah, berdasarkan data awal mengenai rencana pendaftaran pasangan calon perseorangan hampir merata pada 12 kabupaten/kota yang menyelenggarakan Pilkada. Salah satu kasus yang cukup menarik adalah informasi pendaftaran calon perseorangan untuk pemilihan walikota/wakil walikota Makassar yang informasi awalnya mencapai empat pasangan calon, karena jumlah pendaftar pada jalur perseorangan lebih dari dua pasangan, KPU Kota Makassar menyediakan tempat untuk pendaftaran dan verifikasi dokumen pencalonan perseorangan pada salah satu hotel di Makassar, namun kenyataannya hingga waktu terakhir pendaftaran calon perseorangan, tidak ada satupun pasangan calon yang mendaftar. ${ }^{10}$

Semangat sejumlah elite politik Kota Makassar yang ingin mengikuti pemilihan walikota Makassar sangatlah besar, berbagai upaya sejumlah pasangan calon mencari dukungan warga sebagaimana yang dipersyaratkan oleh undang-undang, namun dukungan yang dibutuhkan agar dapat mendaftar sebagai pasangan calon tidak terpenuhi dan faktor-faktor lain yang ikut mempengaruhi sejumlah pasangan mengurungkan niatnya melalui jalur perseorangan. Menurut penyelenggara ad hoc di Makassar bahwa kegagalan sejumlah calon mendaftar sebagai pasangan calon perseorangan pada Pilkada Kota Makassar karena beratnya persyaratan yang harus dipenuhi dan prosesnya yang panjang. ${ }^{11}$

Berdasarkan data calon perseorangan pada dua belas kabupaten/kota yang menyelenggarakan Pilkada, calon perseorangan yang mendaftar dan dokumen pendaftarannya diterima oleh KPU untuk diteruskan hanya pada dua kabupaten yakni Kabupaten Maros dan Kabupaten Kepulauan Selayar, sementara pada kabupaten/kota yang lain sejak awal tidak melakukan proses pendaftaran. Ini bisa menjadi pertanda bahwa elite-elite politik belajar dari pengalaman betapa sulitnya persyaratan yang harus dipenuhi untuk maju sebagai calon perseorangan dalam Pilkada.

\footnotetext{
${ }^{10}$ Bincang-bincang dengan PPK Kota Makassar yang telah mempersiapkan tempat untuk menerima pendaftaran pasangan calon perseorangan pada Pilkada Kota Makassar Tahun 2020.

${ }^{11}$ Fauzi, Anggota Panwascam Mariso, wawancara, 19 November 2020.
} 
Pasangan calon yang benar-benar melakukan pendaftaran ke KPU hanya dua calon perseorangan, yakni Dr. H. Zainuddin dan Aji Sumarno di Kabupaten Kepulauan Selayar dan Muhammad Nur dan Muhammad Ilyas Cika di Kabupaten Maros. Dokumen yang diterima dari pasangan calon perseorangan, KPU melakukan verifikasi, baik verifikasi terhadap dokumen pencalonan yang disetorkan kepada KPU maupun verifikasi hasil perbaikan dan verifikasi faktual di lapangan, calon perseorangan yang memenuhi syarat maju sebagai calon adalah pasangan calon perseorangan di Kepulauan Selayar yakni pasangan Dr. H. Zainuddin dan Aji Sumarno, ${ }^{12}$ pasangan ini berhasil mengumpulkan dukungan berdasarkan ketentuan peraturan perundang-undangan. Berdasarkan ketentuan bahwa daerah kabupaten yang jumlah penduduknya sampai dengan 250.000 hanya memerlukan dukungan 6,5\% yakni sekitar 9.161 dukungan.

Sementara pasangan calon perseorangan pada Pilkada Kabupaten Maros yakni Muhammad Nur dan Muhammad Ilyas Cika harus mengumpulkan dukungan suara minimal 5\% dari total penduduk Maros berdasarkan hasil sensus penduduk tahun 2017 yang mencapai 346.383 jiwa. Jumlah yang dibutuhkan untuk memenuhi syarat minimal pencalonan tidak sedikit yakni 24.505 dukungan, dari total jumlah Daftar Pemilih Tetap (DPT) yang mencapai 245.041 pemilih. ${ }^{13}$ Beratnya memperoleh dukungan suara yang mencapai 24.505, pasangan calon perseorangan Kabupaten Maros gagal memenuhi dukungan minimal yang dipersyaratkan, itupun setelah dilakukan perbaikan dan verifikasi lapangan oleh KPU.

Berdasarkan regulasi yang mengatur mengenai calon perseorangan ditentukan bahwa bakal pasangan calon yang mendaftar pada KPU dilakukan oleh pimpinan partai politik tersebut pada tingkatan masing-masing, apabila ada sesuatu yang menyebabkan tidak dapat dilakukan oleh pimpinan partai pada provinsi/kabupaten/kota, maka dapat dilakukan oleh pimpinan partai tingkat pusat. Sementara calon perseorangan dapat mendaftarkan diri sebagai Pasangan Calon Gubernur dan Wakil Gubernur, Bupati dan Wakil Bupati dan/atau Walikota dan Wakil Walikota jika memperoleh dukungan

12Pasangan pada akhirnya dapat memenuhi syarat minimal dukungan untuk maju sebagai pasangan calon perseorangan, namun dukungan tersebut tidak digunakan, karena belakangan pasangan ini juga berburu rekomendasi partai politik, akhirnya memperoleh dukungan dari Partai Demokrat, Partai Kebangkitan Bangsa dan Partai Keadilan Sejahtera, rekomendasi partai inilah yang digunakan untuk mendaftarkan diri kepada KPU Kabupaten Kepulauan Selayar.

${ }^{13}$ Komisi Pemilihan Umum Kabupaten Maros, "Jumlah Minimum Dukungan dan Persebaran Paslon Perseorangan di Pilkada Maros Tahun 2020” dalam http://kab.maros.kpu.go.id.2019/10 diakses 1 Mei 2021. 
penduduk sebagaimana yang disebutkan dalam Pasal 41 ayat 1 untuk calon gubernur dan ayat 2 untuk calon bupati dan walikota mengenai sebaran jumlah penduduk. ${ }^{14}$ Jumlah dukungan sebagaimana dimaksud pada huruf a, huruf $b$, huruf $c$, dan huruf $d$ tersebar dilebih dari 50\% jumlah kecamatan di kabupaten/kota dimaksud.

Kedua, perebutan rekomendasi partai politik berlangsung sangat dinamis antar elite politik yang memiliki keinginan untuk menjadi calon pada Pilkada serentak 2020. Dinamika perebutan rekomendasi berlangsung antara pasangan calon dengan partai politik yang memenuhi syarat mengusung pasangan calon. Negosiasi pasangan calon dengan partai politik pendukung berlangsung dalam rangka membangun kesamaan visi, misi dan program serta komitmen politik yang disepakati bersama oleh partai pendukung pasangan calon.

Dalam proses perebutan dukungan partai politik, terdapat pasangan calon kepala daerah tertentu yang mengalami dinamika yang terbuka dalam perebutan dukungan partai politik, yakni pencalonan Muhammad Ali Yusuf-Andi Edy Manaf yang semula memperoleh dukungan dari PAN, Gerindra, PKS, Berkarya dan Partai Demokrat, namun menjelang proses pendaftaran sudah dinyatakan aman oleh tim pendukung pasangan tersebut. Namun sehari sebelum pendaftaran di buka oleh KPU Kabupaten Bulukumba, dukungan Partai Demokrat berpindah ke pasangan Andi Hamzah PangkiAndi Nurmi yang memperoleh dukungan Partai Golkar dan Partai Demokrat, Andi Nurmi sendiri merupakan kader Partai Demokrat dan berhasil meyakinkan DPP Partai Demokrat untuk mendukung pasangan yang diusung Partai Golkar dan Partai Demokrat, akhirnya dukungan Partai Demokrat kepada Ali Yusuf-Andi Edy Manaf batal, sekaligus mengurangi jumlah partai pendukung pasangan ini dan konsekuensinya

\footnotetext{
${ }^{14}$ Khusus untuk pencalonan bupati dan walikota ditentukan jumlah dukungan berdasarkan ketentuan pasal 41 ayat 2 dan juga dijelaskan dalam Pasal 10 PKPU No. 3 Tahun 2017 (1) Persyaratan pencalonan berupa jumlah dukungan bagi calon perseorangan untuk Pemilihan Bupati dan Wakil Bupati atau Walikota dan Wakil Walikota, sebagaimana dimaksud dalam Pasal 8 ayat (1), adalah: a. kabupaten/kota dengan jumlah penduduk yang termuat dalam daftar pemilih tetap pada Pemilu atau Pemilihan Terakhir sampai dengan 250.000 (dua ratus lima puluh ribu) jiwa harus didukung paling sedikit 10\%; b. kabupaten/kota dengan jumlah penduduk yang termuat dalam daftar pemilih tetap pada Pemilu atau Pemilihan Terakhir lebih dari 250.000 (dua ratus lima puluh ribu) sampai dengan 500.000 (lima ratus ribu) jiwa harus didukung paling sedikit 8,5\%; c. kabupaten/kota dengan jumlah penduduk yang termuat dalam daftar pemilih tetap pada Pemilu atau Pemilihan Terakhir lebih dari 500.000 (lima ratus ribu) sampai dengan 1.000 .000 (satu juta) jiwa harus didukung paling sedikit 7,5\%; atau d. kabupaten/kota dengan jumlah penduduk yang termuat dalam daftar pemilih tetap pada Pemilu atau Pemilihan Terakhir lebih dari 1.000 .000 (satu juta) jiwa harus didukung paling sedikit $6,5 \%$.
} 
menambah jumlah pasangan calon dalam Pilkada di Kabupaten Bulukumba, sehingga jumlah pasangan calon menjadi empat.

Perebutan rekomendasi partai politik tidak hanya terjadi di Kabupaten Bulukumba, tetapi juga terjadi pada semua daerah yang menyelenggarakan Pilkada. Akibat saling rebut rekomendasi partai, begitu KPU membuka pendaftaran pasangan secara resmi, hampir sebagian besar pasangan calon yang gonjang ganjing dukungan politiknya, melakukan pendaftaran pada hari pertama, seperti pasangan calon di Kota Makassar (beberapa pasangan calon rekomendasi partai politik tidak stabil), Bulukumba (dilakukan oleh pasangan yang memastikan bahwa rekomendasi DPP partai politik sudah aman), Pangkajene Kepulauan, Barru dan daerah lainnya yang telah memenuhi ketentuan undang-undang segera mendaftar pada waktu pertama.

Persetujuan dari pimpinan pusat partai politik tidak diperoleh dengan mudah oleh pasangan calon, tetapi melalui tahapan panjang, mulai dari survei elektabilitas, mendaftar pada partai politik di kabupaten/kota, penyampaian visi-misi dan program dan persyaratan lainnya. Selain tahapan tersebut, pasangan calon untuk beberapa partai politik diwajibkan membayar "mahar politik" kepada pimpinan partai, besarnya bervariasi dari satu partai ke partai lainnya. Praktik politik uang sudah terjadi pada tahap pendaftaran di partai politik, adanya keharusan membayar "mahar politik" menjadi beban bagi pasangan calon, meskipun ada partai politik yang tidak mewajibkannya. ${ }^{15}$

Pasangan yang memperoleh dukungan partai politik atau gabungan partai politik yang diterima pendaftarannya oleh KPU adalah yang memenuhi persyaratan $20 \%$ perolehan kursi DPRD atau 25\% perolehan suara sah pada Pemilu. Setiap partai politik hanya dapat mengusulkan atau mendaftarkan satu pasangan calon; partai politik dapat bersepakat dengan partai politik lain untuk membentuk gabungan dalam mendaftarkan bakal pasangan calon; partai politik atau gabungan partai politik melakukan kesepakatan dengan bakal pasangan calon untuk didaftarkan mengikuti pemilihan; partai politik atau gabungan partai politik yang telah mendaftarkan bakal pasangan calon kepada KPU Provinsi/KIP Aceh atau KPU/KIP Kabupaten/Kota, tidak dapat menarik dukungannya sejak pendaftaran; dalam hal partai politik atau gabungan partai politik menarik

\footnotetext{
${ }^{15}$ Untuk bahasan mengenai politik uang, dapat dilihat dalam Syarifuddin Jurdi, "Politik Uang dalam Pemilu Indonesia“ dalam Jurnal Pustaka Pemilu, Vol. 1 No. 2, (2019); Edward Arspinall \& Ward Berenschot, Democracy for Sale: Elections, Clientalism and the State in Indonesia (Ithaca: Cornell University, 2019).
} 
dukungan dan/atau menarik bakal calon dan/atau bakal pasangan calon yang telah didaftarkan, partai politik atau gabungan partai politik tersebut dianggap tetap mendukung bakal pasangan calon yang bersangkutan dan tidak dapat mengusulkan bakal calon atau bakal pasangan calon pengganti; bakal calon yang telah menandatangani kesepakatan pengusulan dan telah didaftarkan kepada KPU Provinsi/KIP Aceh atau KPU/KIP Kabupaten/Kota, tidak dapat mengundurkan diri sejak pendaftaran; dalam hal bakal calon sebagaimana dimaksud pada ayat 6 mengundurkan diri, partai politik atau gabungan partai politik yang mencalonkan tidak dapat mengusulkan bakal calon dan/atau bakal calon pengganti dan pencalonannya dinyatakan gugur. ${ }^{16}$

Bakal pasangan calon yang akan mendaftaran diri sebagaimana ketentuan pasal 39 ayat 3 disebutkan bahwa dalam mendaftarkan Bakal Pasangan Calon oleh Partai Politik atau Gabungan Partai Politik sebagaimana dimaksud pada ayat 1 dan ayat 2, partai politik atau gabungan partai politik harus memenuhi persyaratan: a. pencalonan sebagaimana dimaksud dalam Pasal 5 ayat 2 dan ayat 3; b. menyertakan surat pencalonan dan kesepakatan Bakal Pasangan Calon dengan partai politik atau gabungan partai politik; c. menyertakan dokumen syarat calon dan surat persetujuan Pasangan Calon yang ditandatangani oleh Pimpinan Partai Politik tingkat pusat; d. menyertakan keputusan Pimpinan Partai Politik tingkat pusat tentang kepengurusan partai politik tingkat provinsi untuk Bakal Pasangan Calon Gubernur dan Wakil Gubernur; e. menyertakan keputusan Pimpinan Partai Politik tingkat pusat atau provinsi tentang kepengurusan partai politik tingkat kabupaten/kota sesuai dengan anggaran dasar dan anggaran rumah tangga partai politik yang bersangkutan, untuk Bakal Pasangan Calon Bupati dan Wakil Bupati atau Walikota dan Wakil Walikota. ${ }^{17}$

Dalam proses pendaftaran sebagai pasangan calon harus disertai oleh Ketua dan Sekretaris Partai Politik pendukung, hal ini ditegaskan bahwa setiap pasangan calon yang mendaftar sebagai peserta pemilihan telah memperoleh dukungan atau keputusan pimpinan partai tingkat pusat, sementara calon perseorangan berdasarkan ketentuan pasal 39 ayat 3c bahwa pasangan calon perseorangan dapat mendaftarkan diri sebagai Pasangan Calon Gubernur dan Wakil Gubernur, Bupati dan Wakil Bupati dan/atau

16Peraturan KPU No. 3 Tahun 2017, Pasal 6.

${ }^{17}$ Ibid., Pasal 39 ayat 3. 
Walikota dan Wakil Walikota jika memenuhi syarat dukungan dan persebaran sebagaimana dimaksud dalam Pasal 9 dan Pasal 10 yang mengatur mengenai besaran jumlah dukungan yang wajib dipenuhi oleh pasangan perseorangan dan sebarannya.

Pasangan calon yang telah memenuhi syarat dukungan partai politik, gabungan partai politik atau dukungan sebagai calon perseorangan akan melakukan pendaftaran, proses pendaftaran dilakukan dengan menyertakan sejumlah syarat pencalonan dan syarat calon, dalam PKPU No. 1 Tahun 2020 point d disebutkan;

\begin{abstract}
"Berdasarkan hasil verifikasi sebagaimana dimaksud dalam huruf b dan huruf c, KPU Provinsi/KIP Aceh atau KPU/KIP Kabupaten/Kota mencatat penerimaan dokumen persyaratan pencalonan dan persyaratan calon yang diajukan oleh Partai Politik atau Gabungan Partai Politik menggunakan Tanda Terima pendaftaran formulir Model TT.1-KWK, yang berisi: 1. nama Partai Politik atau Gabungan Partai Politik yang mendaftarkan Bakal Pasangan Calon; 2. nomor dan tanggal keputusan Pimpinan Partai Politik tingkat pusat dan/atau keputusan Pimpinan Partai Politik tingkat provinsi sebagaimana dimaksud dalam huruf c; 3. nomor dan tanggal Keputusan Pimpinan Partai Politik tingkat pusat tentang persetujuan Bakal Pasangan Calon yang diusulkan oleh pengurus Partai Politik tingkat provinsi atau pengurus Partai Politik tingkat kabupaten/kota, yang ditandatangani oleh Ketua Umum dan Sekretaris Jenderal atau nama lain Pimpinan Partai Politik tingkat pusat; 4. hari, tanggal, dan waktu penerimaan dokumen persyaratan pencalonan dan persyaratan calon; 5. alamat dan nomor telepon bakal calon, alamat dan nomor telepon kantor Pimpinan Partai Politik atau masing-masing kantor Pimpinan Partai Politik yang bergabung mendaftarkan Bakal Pasangan Calon; dan 6. jumlah dan jenis kelengkapan dokumen persyaratan pencalonan dan persyaratan calon".
\end{abstract}

Ketiga, terdapat dua kabupaten yang memiliki calon tunggal yakni Kabupaten Gowa dan Kabupaten Soppeng, kedua kabupaten ini dinamika politiknya relatif stabil, proses pencalonan pada dua daerah ini juga berjalan aman dan lancar, waktu pendaftaran pun tidak terlalu bermasalah. Munculnya calon tunggal merupakan hasil dari proses politik selama lima tahun terakhir, incumbent dianggap sebagai figur yang kuat, ketokohannya kuat, partai-partai politik menganggap figur incumbent perlu dipertahankan. Sementara dari kalangan masyarakat sendiri, penerimaan terhadap figur incumbent, baik di Kabupaten Gowa maupun Kabupaten Soppeng sangat baik, sehingga tidak ada elite politik atau tokoh masyarakat yang berniat untuk mencalonkan diri melalui jalur perseorangan. Incumbent Kabupaten Gowa pada lima tahun yang lalu ketika Pilkada serentak pertama diselenggarakan maju sebagai calon perseorangan, 
meski ada partai yang mendukung. Namun tahun 2020, semua partai politik sepakat mendukung incumbent.

Pencalonan merupakan arena yang ditentukan oleh peraturan perundangundangan, dalam Undang-Undang No. 8 Tahun 2015 Pasal 40 ayat (1) disebutkan bahwa "partai politik atau gabungan partai politik dapat mendaftarkan pasangan calon apabila memenuhi perolehan jumlah kursi DPRD minimal 20\% atau memperoleh $25 \%$ akumulasi suara sah dalam Pemilu anggota DPRD di daerah yang bersangkutan”. Potensi lahirnya calon kepala daerah akan ditentukan oleh partai politik yang memperoleh dukungan suara dan atau dukungan kursi parlemen, konsekuensi yang dihasilkan dari regulasi ini berpotensi melahirkan calon tunggal, apabila partai politik yang memperoleh kursi parlemen memberikan rekomendasi dan dukungan kepada satu pasangan calon, sementara calon perseorangan tidak muncul. Itulah yang terjadi pada Kabupaten Gowa dan Kabupaten Soppeng yang memunculkan calon tunggal.

Faktor lain yang menyebabkan kurangnya peminat yang mendaftar pada partai politik, karena mahalnya mahar politik. Istilah mahar politik ini sebagai satu konsekuensi logis dari rekrutmen politik yang bersifat terbuka, menurut Soepiadhy, ${ }^{18}$ bahwa ada kegiatan transaksional yang melanggar regulasi, dengan cara memberikan sejumlah dana untuk jabatan politik yang akan diperebutkan dalam pemilihan dengan partai politik sebagai kendaraan politiknya.

Calon perseorang dalam Pilkada telah ada sejak keluarnya putusan MK No. 5/PUU-V/2007, calon perseorangan dianggap menjadi pintu alternatif yang memberikan pilihan yang bervariasi kepada pemilih, tentu dengan sejumlah keunggulan yang dimiliki oleh kandidat. Calon tunggal dikuatkan oleh Putusan Mahkamah Konstitusi No 100/PUU-XIII/ 2015 menyatakan Pasal 50 ayat 9 Undang-Undang Nomor 8 Tahun 2015 tidak mempunyai kekuatan hukum mengikat sepanjang tidak dimaknai mencakup pengertian "termasuk menetapkan 1 (satu) pasangan calon bupati dan calon wakil bupati serta 1 (satu) pasangan calon walikota dan calon wakil walikota peserta pemilihan dalam hal setelah jangka waktu 3 (tiga) hari dimaksud terlampaui namun tetap hanya ada 1 (satu) pasangan calon bupati dan calon wakil bupati serta 1 (satu) pasangan calon walikota dan calon wakil walikota".

${ }^{18}$ Endah Yuli Ekowati, " Pragmatisme Politik: Antara Koalisi, Pencalonan, dan Calon Tunggal Dalam Pilkada” dalam Jurnal Transformative, Vo. 5, No. 1 (2019). 
Calon tunggal dalam Pilkada di Sulawesi Selatan bukanlah yang pertama, pada Pilkada serentak 2018, terdapat tiga kabupaten/kota yang pasangan calon tunggal yakni Kabupaten Enrekang, Kabupaten Bone dan Kota Makassar, untuk yang disebut terakhir harus dilakukan Pilkada ulang, karena suara pasangan calon dikalahkan oleh kolom kosong. Munculnya calon tunggal pada dasarnya meniadakan kontestasi dan kompetisi untuk memilih kepala daerah yang terbaik. Pilkada tanpa kompetisi dan kontestasi akan terasa hampa dan tidak ada alternatif pilihan rakyat, sehingga makna dan arti dari prinsip Pemilu yang langsung, umum, bebas, rahasi, jujur dan adil terasa normatif semata tanpa substansi.

Keempat, pasangan calon yang telah dinyatakan oleh KPU sebagai calon yang memenuhi syarat berdasarkan dokumen pencalonannya, segera melakukan proses pemeriksaan kesehatan sebagai satu tahapan krusial untuk memastikan bahwa pasangan calon yang dinyatakan memenuhi syarat berdasarkan dokumen pencalonan akan mengikuti proses pemeriksaan kesehatan. Pada pemilihan serentak 2020, persyaratan yang harus dipenuhi oleh pasangan calon adalah persyaratan kesehatan yang telah diatur seperti test lengkap kesehatan, test narkoba dan test psikologi, juga harus dinyatakan negatif test Covid-19, meski tidak diatur dalam undang-undang Pilkada, tetapi menjadi satu kewajiban baru bagi seluruh warga negara, termasuk calon kepala daerah. ${ }^{19}$

Proses pemeriksaan kesehatan terkendala pada dua kabupaten yang pasangan calonnya dinyatakan positif Covid-19 yakni Kabupaten Luwu Timur pasangan nomor urut 2 dinyatakan positif Covid-19 dan melakukan isolasi sampai dinyatakan sembuh dari Covid-19, setelah itu dilakukan pemeriksaan kesehatan, menurut M. Abu (anggota KPU Lutim) bahwa pasangan calon nomor urut 2 yang mengalami penundaan penetapannya, karena positif Covid-19. ${ }^{20}$ Sementara pada Kabupaten Luwu Utara juga mengalami keadaan yang sama bahwa terdapat pasangan calon yang positif Covid-19 dan dirawat pada salah satu rumah sakit di Makassar. Mengenai pasangan calon Luwu Utara yang sakit pada saat pemeriksaan kesehatan, KPU RI memberi arahan kepada

${ }^{19}$ Test Covid-19 merupakan satu tahapan krusial, karena test covid akan menentukan proses test yang lain. Tim kesehatan, tim test narkoba dan psikologi tidak akan melakukan pemeriksaan terhadap pasangan calon yang dinyatakan positif Covid-19, karena tim kesehatan rawan akan tertular oleh virus tersebut. Oleh sebab itu, sehat Covid-19 merupakan prasyarat utama untuk bisa melakukan proses pemeriksaan kesehatan, narkoba dan psikologi. 2021.

${ }^{20}$ Muhammad Abu, Anggota KPU Luwu Timur-Divisi Teknis Penyelenggaraan, wawancara, 25 April 
KPU Luwu Utara agar melakukan klarifikasi ke rumah sakit tempat yang bersangkutan dilakukan perawatan dan pemeriksaan kesehatan tetap dilakukan sesuai dengan prosedur yang telah ditetapkan oleh KPU RI melalui Keputusan KPU No. 412/PL.02Kpt/06/KPU/IX/2020 tentang Pedoman Teknis Standar Kemampaun Jasmani dan Rohani dan Bebas Penyalahgunaan Narkotika dalam Pemilihan Gubernur dan Wakil Gubernur, Bupati dan Wakil Bupati, dan/atau Walikota dan Wakil Walikota Tahun 2020.

Adanya pasangan calon yang tiba-tiba sakit pada saat dimulainya pemeriksaan kesehatan dapat dianggap sebagai fenomena unik, setidaknya muncul pertanyaan; apakah pasangan calon sedang dalam posisi sakit karena Covid-19 ataukah yang bersangkutan memang mengidap penyakit tertentu yang sebenarnya bisa mempengaruhi proses pencalonannya sebagai pasangan calon kepala daerah?. Oleh sebab itu, KPU RI meminta KPU Luwu Utara untuk melakukan klarifikasi kepada pihak rumah sakit yang merawatnya dan mengambil kebijakan berdasarkan tahapan pemilihan yang telah ditetapkan oleh KPU RI.

Hasil pemeriksaan kesehatan terhadap seluruh pasangan calon pada 12 kabupaten/kota yang menyelenggarakan Pilkada serentak 2020 di wilayah Sulawesi Selatan pada umumnya sehat, termasuk pasangan calon yang dinyatakan positif Covid19 di Kabupaten Luwu Utara dan Kabupaten Luwu Timur, tetapi ada satu pasangan calon yang dinyatakan positif Narkoba oleh Tim pemeriksa dari Badan Narkotika. Terhadap pasangan calon yang dinyatakan positif Narkoba, berdasarkan ketentuan Peraturan KPU menyebutkan bahwa;

"Tim pemeriksa kesehatan sebagaimana dimaksud pada ayat (3) melakukan rapat pleno untuk menetapkan kesimpulan yang menyatakan: a. calon mampu atau tidak mampu secara jasmani dan rohani; dan b. positif atau negatif menyalahgunakan narkotika, yang ditandatangani oleh ketua tim pemeriksa kesehatan. Tim pemeriksa kesehatan menyampaikan kesimpulan sebagaimana dimaksud pada ayat (8) dengan dilampiri seluruh hasil pemeriksaan kesehatan calon kepada KPU Provinsi/KIP Aceh atau KPU/KIP Kabupaten/Kota, sebagai pemenuhan kelengkapan persyaratan calon. Kesimpulan dan seluruh hasil pemeriksaan kesehatan sebagaimana dimaksud pada ayat (8) dan ayat (9) bersifat final dan tidak dapat dilakukan pemeriksaan pembanding". ${ }^{21}$

${ }^{21}$ Peraturan KPU No. 3 Tahun 2017, Pasal 46 ayat 8, 9, 10. 
Peraturan tersebut di atas menegaskan bahwa pasangan calon yang dinyatakan tidak sehat dan atau positif menyalahgunakan narkotika, maka kesimpulan tim kesehatan yang melakukan pemeriksaan menyeluruh dinyatakan final dan mengikat, tidak ada upaya banding atau keberatan terhadap kesimpulan tim kesehatan. Oleh sebab itu, pasangan calon pada salah satu kabupaten di Sulawesi Selatan yang disimpulkan oleh tim kesehatan positif narkotika dinyatakan gugur dan harus diusulkan calon pengganti. Tim pemeriksa kesehatan, narkotika dan psikologi merupakan tim independen yang tidak bisa diintervensi oleh penyelenggara Pemilu dan ataupun pihak lain, mereka terikat dengan kote etik dan nilai-nilai moral dalam menjalankan tugasnya.

\section{Pendaftaran dan Penetapan Pasangan Calon}

Pasangan calon ditetapkan sebagai pasangan yang akan mengikuti pemilihan tidak semata-mata didasarkan pada dokumen pencalonan, persyaratan pencalonan atau syarat calon, tetapi mencakup seluruh dokumen terkait, termasuk hasil pemeriksaan kesehatan, narkotika dan psikologi. Oleh sebab itu, KPU melakukan tahapan; Pertama, memeriksa seluruh dokumen pencalonan yang memuat syarat pencalonan dan syarat calon; Kedua, untuk pasangan calon independen dilakukan verifikasi faktual terhadap dukungan pencalonan sebelum dilakukan penetapan pasangan calon; Ketiga, syarat kesehatan merupakan salah satu syarat penting, karena mencakup dua hal: 1). Syarat kesehatan yang dilakukan pemeriksaan oleh Rumah Sakit Pemerintah yang ditunjuk bekerjasama dengan Ikatan Dokter Indonesia, Badan Narkotika dan Ikatan Psikologi; 2). Pasangan calon dinyatakan sehat dari virus Covid-19.

Penetapan pasangan calon merupakan tahapan yang sangat penting bagi peserta pemilihan, karena penetapan pasangan calon merupakan pintu untuk melakukan proses selanjutnya. KPU sebagai penyelenggara teknis Pemilu sebelum menetapkan pasangan calon yang dianggap memenuhi syarat, diawali dengan proses verifikasi seluruh dokumen yang menjadi kewajiban pasangan calon berdasarkan ketentuan peraturan perundang-undangan. Syarat calon yang ditetapkan oleh undang-undang mencakup; ${ }^{22}$

22Undang-Undang Nomor 1 Tahun 2015 Tentang "Penetapan Peraturan Pemerintah Pengganti Undang-Undang Nomor 1 Tahun 2014 tentang Pemilihan Gubernur, Bupati, dan Walikota Menjadi UndangUndang", Pasal 7. 
“a. bertakwa kepada Tuhan Yang Maha Esa; b. setia kepada Pancasila, UndangUndang Dasar Negara Republik Indonesia Tahun 1945, cita-cita Proklamasi Kemerdekaan 17 Agustus 1945, dan Negara Kesatuan Republik Indonesia; c. berpendidikan paling rendah sekolah lanjutan tingkat atas atau sederajat; d. telah mengikuti Uji Publik; e. berusia paling rendah 30 (tiga puluh) tahun untuk Calon Gubernur dan 25 (dua puluh lima) tahun untuk Calon Bupati dan Calon Walikota; f. mampu secara jasmani dan rohani berdasarkan hasil pemeriksaan kesehatan menyeluruh dari tim dokter; g. tidak pernah dijatuhi pidana penjara berdasarkan putusan pengadilan yang telah mempunyai kekuatan hukum tetap karena melakukan tindak pidana yang diancam dengan pidana penjara 5 (lima) tahun atau lebih; h. tidak sedang dicabut hak pilihnya berdasarkan putusan pengadilan yang telah mempunyai kekuatan hukum tetap; i. tidak pernah melakukan perbuatan tercela; j. menyerahkan daftar kekayaan pribadi; k. tidak sedang memiliki tanggungan utang secara perseorangan dan/atau secara badan hukum yang menjadi tanggung jawabnya yang merugikan keuangan negara; 1 . tidak sedang dinyatakan pailit berdasarkan putusan pengadilan yang telah mempunyai kekuatan hukum tetap; m. memiliki Nomor Pokok Wajib Pajak dan memiliki laporan pajak pribadi; n. belum pernah menjabat sebagai Gubernur, Bupati, dan Walikota selama 2 (dua) kali masa jabatan dalam jabatan yang sama; o. berhenti dari jabatannya bagi Gubernur, Bupati, dan Walikota yang mencalonkan diri di daerah lain; p. tidak berstatus sebagai penjabat Gubernur, penjabat Bupati dan penjabat Walikota; q. tidak memiliki konflik kepentingan dengan petahana; r. memberitahukan pencalonannya sebagai Gubernur, Bupati, dan Walikota kepada Pimpinan Dewan Perwakilan Rakyat bagi anggota Dewan Perwakilan Rakyat, kepada Pimpinan Dewan Perwakilan Daerah bagi anggota Dewan Perwakilan Daerah, atau kepada Pimpinan DPRD bagi anggota DPRD; s. mengundurkan diri sebagai anggota Tentara Nasional Indonesia, Kepolisian Negara Republik Indonesia, dan Pegawai Negeri Sipil sejak mendaftarkan diri sebagai calon; dan t. berhenti dari jabatan pada badan usaha milik negara atau badan usaha milik daerah".

Selain syarat tersebut dipenuhi oleh pasangan calon, juga harus memenuhi syarat pencalonan yakni dukungan partai politik peserta politik yang ditentukan oleh undangundang. Pasangan calon hanya dianggap sah dan memenuhi syarat pencalonan apabila didukung oleh partai politik atau gabungan partai politik yang memperoleh dukungan kursi DPRD sebanyak 20\% atau dukungan suara sah 25\%, serta calon perseorangan yang tidak menggunakan jaringan partai politik, tetapi dukungan langsung warga yang dibuktikan dengan fotocopy KTP yang telah diverifikasi secara faktual oleh KPU.

Pada tahapan pendaftaran pasangan calon, partai politik atau gabungan partai politik ketika mendaftarkan pasangan calon terdapat beberapa yang tidak menaati protokol kesehatan. Pada pihak penyelenggara, standar protokol kesehatan dapat ditegakkan, karena jumlah orang yang bisa memasuki area pendaftaran dibatasi sesuai 
standar protokol kesehatan, namun jumlah massa yang ikut mengantar pasangan calon mendaftar yang jauh lebih besar tidak dapat dikontrol oleh KPU. Namun pengawas pemilihan dan Satuan Tugas Covid-19 memiliki catatan tersendiri mengenai kepatuhan pasangan calon dalam menerapkan protokol kesehatan.

Berdasarkan data mengenai penerapan protokol kesehatan oleh pasangan calon, secara umum pada hampir semua daerah yang menyelenggarakan pemilih di Sulawesi Selatan sulit mengontrol massa pendukungnya, namun ada pasangan calon yang tidak menyertakan massa pendukung sama sekali pada proses pendaftarannya. Sejumlah incumbent yang mendaftar dan tidak menerapkan protokol kesehatan memperoleh teguran langsung dari Menteri Dalam Negeri. Beberapa incumbent yang tidak taat protokol kesehatan tersebut, di antaranya; Bupati Luwu Timur Muh. Thoriq Husler, Wakil Bupati Luwu Utara Muh. Thahar Rum, Wakil Bupati Luwu Timur Irwan Bachri, Wakil Bupati Maros Andi Harmil Mattotorang, dan Wakil Bupati Bulukumba Tomy Satria Yulianto. Incumbent ini dalam pemberitaan media (gambar, video dll.) diketahui memobilisasi massa pendukung yang menyebabkan terjadinya kerumunan massa.

\section{Kesimpulan}

Dinamika pencalonan kepala daerah di Sulawesi Selatan pada Pilkada serentak tahun 2020 menunjukkan eskalasi politik yang meningkat pada beberapa kabupaten/kota yang jumlah pasangan calonnya lebih dari dua pasangan, sementara pada dua kabupaten yang memunculkan pasangan calon tunggal dinamika dan eskalasi politiknya stabil. Berdasarkan analisa dari informasi proses pencalonan kepala daerah di Sulawesi Selatan diperoleh fakta; Pertama, jumlah pasangan calon pada masing-masing kabupaten/kota bervariasi. Daerah yang memiliki empat pasangan calon, yakni Kabupaten Bulukumba dan Kota Makassar. Kabupaten yang memiliki tiga pasangan calon, yakni Kabupaten Maros, Kabupaten Pangkajene Kepulauan, Kabupaten Barru, Kabupaten Luwu Utara, Kabupaten Tana Toraja dan Kabupaten Toraja Utara, sedangkan yang memiliki dua pasangan calon yakni Kabupaten Kepulauan Selayar dan Kabupaten Luwu Timur sementara calon tunggal pada Kabupaten Gowa dan Kabupaten Soppeng.

Kedua, jumlah calon perseorangan yang memenuhi syarat setelah dilakukan verifikasi faktual hanya satu pasangan calon di Kabupaten Kepulauan Selayar. Hanya 
saja, pasangan calon yang memenuhi syarat pencalonan untuk jalur perseorangan di Kepulauan Selayar tidak mendaftar melalui jalur perseorangan, tetapi menggunakan jalur partai politik. Ketiga, calon tunggal justru muncul pada dua daerah yang dalam tradisi Pilkada secara langsung selalu memunculkan calon yang kompetisi dan kontestasinya sangat tinggi yakni pada Kabupaten Soppeng (pada dua Pilkada sebelumnya, rivalitas memanas antar pendukung pasangan calon di kabupaten ini, bahkan kantor KPU menjadi sasaran massa) dan Kabupaten Gowa yang dalam tiga kali Pilkada langsung sebelumnya selalu diwarnai dengan kontestasi antar kandidat, pada lima tahun lalu, kantor KPU juga menjadi sasaran dan kantor DPRD Kabupaten Gowa. Pada Pilkada 2020, dua kabupaten tersebut justru rivalitas dan kontestasinya tidak ada, karena memunculkan pasangan calon tunggal. Keempat, calon perseorangan hanya satu pasangan calon, namun dukungan sebagai calon perseorangan tidak digunakan, karena calon yang bersangkutan justru mendaftar dengan dukungan partai politik.

\section{DAFTAR PUSTAKA}

Arspinall, Edward \& Ward Berenschot. Democracy for Sale: Elections, Clientalism and the State in Indonesia. Ithaca: Cornell University, 2019.

Asy'ari, Hasyim. Konsolidasi Demokrasi: Pergulatan Politik Pemilu di Indonesia. Yogyakarta: Thafa Media, 2019.

Bleicher, Josef. Contemporary Hermeneutics: Hermeneutics as Method, Philosophy and Critique. London: Routledge, 1980.

Ekowati, Endah Yuli. " Pragmatisme Politik: Antara Koalisi, Pencalonan, dan Calon Tunggal Dalam Pilkada” dalam Jurnal Transformative, Vo. 5, No. 1 (2019), h. 16-37.

Gaffar, Afan. Politik Indonesia; Transisi Menuju Demokrasi. Yogyakarta: Pustaka Pelajar, 1999.

Jurdi, Syarifuddin. "Politik Uang dalam Pemilu Indonesia" dalam Jurnal Pustaka Pemilu, Vol. 1 No. 2, (2019).

- Pemilihan Umum di Indonesia: Tata Kelola Pemilu, Kedaulatan Rakyat dan Demokratisasi. Jakarta: Kencana Prenada Media Gorup, 2020.

Mudiyati, Rahmatunnisa. "Desentralisasi dan Demokrasi” dalam Jurnal Governance, Vol 1, No 2 (2012), h. 1-21. 
Prihatmoko, Joko J. Mendemokrasikan Pemilu: Dari Sistem Sampai Elemen Teknis. Yogyakarta: Pustaka Pelajar, 2008.

Surbakti, Ramlan, dkk. Naskah Akademik dan Draft RUU Kitab Hukum Pemilu: Usulan Masyarakat Sipil. Jakarta: Kemitraan bagi Pembaruan Tata Pemerintahan di Indonesia, 2015.

Memahami Ilmu Politik. Jakarta: Erlangga, 1992.

\section{Internet}

Komisi Pemilihan Umum Kabupaten Maros. "Jumlah Minimum Dukungan dan Persebaran Paslon Perseorangan di Pilkada Maros Tahun 2020" dalam http://kab.maros.kpu.go.id.2019/10 diakses 1 Mei 2021.

\section{Wawancara}

Muhammad Abu, Anggota KPU Luwu Timur-Divisi Teknis Penyelenggaraan, wawancara, 25 April 2021.

Fauzi, Anggota Panwascam Mariso, wawancara, 19 November 2020. 